\title{
A reflective study on Indonesian English teacher's expectation from teacher forum for professional development
}

\author{
Sueb $^{1}$, Ririn Pusparini ${ }^{2}$, Anis Trisusana ${ }^{3}$, Esti Kurniasih ${ }^{4}$, Nur Chakim $^{5}$ \\ 1,2,3,4,5 Department of English, Universitas Negeri Surabaya, Indonesia \\ ${ }^{1}$ sueb@unesa.ac.id, ${ }^{2}$ ririnpusparini@unesa.ac.id , ${ }^{3}$ anistrisusana@unesa.ac.id, \\ ${ }^{4}$ estikurniasih@unesa.ac.id, ${ }^{5}$ nurchakim@unesa.ac.id \\ *) correspondence: sueb@unesa.ac.id
}

\begin{abstract}
Teacher professional development is an ongoing process. Standing on the frontline in implementing educational policies, teachers are encouraged to actualize both theoretically, policies, and practices. One way to improve the professionalism of a teacher is reflection through an academic forum so as to enrich the inquiry obtained in order to improve individual professionalism. This is an ongoing research involving English teachers in East Java members of the ELT Best Practices academic forum. The goal is to elaborate two basic things, namely the motivation of teachers in their involvement in academic forums and how academic forums can help them in conducting self-reflection in order to increase professionalism. Almost all teachers say that increasing professionalism as an English teacher is the main motivation. In detail, several aspects that are the focus of improvement are language skills, teaching techniques, the renewal of language teaching theories, and increasing networking among English teacher professions. With diverse backgrounds ranging from English teachers in middle and high school (or similar), the academic forum is considered important to help the teachers upgrade their knowledge and professionalism.
\end{abstract}

Keywords: academic forum; professional development; reflection; ELT best practices

\section{INTRODUCTION}

Assessing teacher competency becomes a vital instrument for policy-making in developed countries. This study seeks to elaborate one practice to assist teacher to reflect what they have done in the teaching practices as well as locate their expectation as part of developing their professionalism.

In general, teacher competency refers to a number of indicators that can be used as a measure of the characteristics of teachers who are judged to be professionally competent, which cover a combination of personal, scientific, technological, social, and spiritual abilities; these aspects are believed to contribute to teacher's mastery in terms of material, understanding of students, learning that educates, personal development, and professionalism (Mulyasa, 2007). In Indonesia, however, the understanding on teacher professional development has been currently limited to seminars and workshops which are dominated by one-way activities; the teachers are positioned as recipients of the materials. Instead of giving opportunity for teachers to enhance their knowledge based on their teaching experience, the teachers are considered as the implementing party (tool). As a result, the ability of teachers tends to stagnate and follow instructions that have been given.

One strategy which is believed to help teachers to develop their professionalism is through reflection. The concept of critical reflection, which is perceived as the higher practice of reflection in professional development, is derived from the idea of John Dewey (Liu, 2015) that "various active, persistent, and careful consideration of any belief or form of knowledge based on further reasons and conclusions that tend to support it". The core of this concept lies on "the idea to systematically and in detail examine an idea, an experience (teaching activity), a problem, with an open-minded attitude, 
wholehearted, curiosity, and responsibility" to develop teaching competencies and abilities. In addition, reflective practice among teachers does not only originate from impulsive and intuitive feelings; rather, it is based on the fact that teachers need to collect systematic evidence (or data) about their works and then make decisions based on this information (Farrell, 2012). Reflective practice is believed to provide opportunities for teachers to think systematically, independently, and collaboratively about their practice, experience, and decision making. Such abilities are to build teacher's autonomy which in turn lead into a more professional individual.

In such more specific context as the teaching of English in Indonesia, there are several challenges besides student motivation, namely mismatch between expectations and reality, lack of quality resources and heavy workload for teachers (Marwan, 2017; Widodo, 2015; Widodo, 2016). However, very little research has been done to date to discuss the strategies of English language teachers in Indonesia in facing the challenges they face in negotiating their teaching practices, especially in their early years of teaching experience. Teachers may face difficulty finding between teaching expectations and reality (Yost, 2006), especially when this is related to the systemic force majeure that is beyond the ability to change that teachers are assigned as the implementer of the policies instead of theorizer of their teaching practices.

Reflective practice may help teachers to deal with the gap; Richards and Farrell (2005) say that reflection for teachers can be seen as a critical self-evaluation process upon their teaching experiences and processes that may lead to a better understanding of their teaching practices and routines. In addition, it was added that the positive impact reported in most of these studies on increasing the level of awareness resulting from such reflections seemed to provide opportunities and further motivation for English teachers to explore further, and even in some cases even challenging, approaches they are currently against practice (Farrell, 2012). In addition, Bruinsma and Jansen (2010) give insight on the importance of adaptive motivation which may facilitate long-term and effective engagement in teaching, such as the prospect of making a good professional career in teaching.

One of the rationalities of the importance of the concept of reflection as an effort to develop the professionalism of a teacher, especially English, is related to the emerging paradigm of postmodernism. In such disruptive era where ideas collide each other, the postmodernism paradigm proposed by Kumaravadivelu (2006) consisting of three main principles, e.g. particularity, practicality, and possibility, stress out the idea that that English teachers are no longer constantly positioned as users or implementers of theory and policies (in contrary with the current professional development practices in Indonesia); teachers are considered as individuals which are able to theorize about their teaching experience.

For this reason, basic measurement skills are needed to guide their teaching experience through reflection upon what they have done and what they expect through academic forum, where possible collaboration and sharing idea may occur. This research will be aimed at facilitating English teachers in conducting critical reflection practices by understanding teaching practices and their relation to the system in which they work. From this we will get English teachers' perceptions about expectations and reality and how teachers synthesize a policy and change based on the results of self-reflection. There are two main objectives discussed in this reflective study, including observing how the motivation of English teachers in one academic forum, how their motivation is related to current trend in the teaching of English. This study is expected to contribute practically as an effort to develop the English teacher professionalism. In addition, it is believed that reflective practice among teachers should become an alternative evaluation of education to improve the quality of education and teacher competition, especially those which are more humane for teachers in the 21 st Century era of disruption. 


\section{A reflective study on Indonesian English teacher's expectation from teacher forum for professional development}

\section{METHODS}

\section{Design}

This is an explanatory sequential study involving English teachers who participated in the ELT Best Practices academic forum. The role of researchers as well as committee of the ELT Best Practices academic forum as the key instrument (Mertens, 2010), in which the researchers had full access to the participants during research to interact intensively and consistently with research subjects (the English teachers in the ELT Best Practices forum) both through formal or informal communication related to their expectations with academic programs that they are participating in or related to learning issues, in order to collect data so as to produce a theory. In addition, the researchers were also expected to be able to have full access in determining the sample to conduct surveys and gather discussions to gather the perceptions of English teachers through focus-group discussion.

\section{Participants}

This study involved English language teachers who were members of ELT Best Practices who participated in the ELT Best Practices academic forum which was held four times a year, namely February, April, September, and November 2019. The ELT Best Practices is an academic forum attended by participants consisted of English teachers, senior undergraduate students, graduate students, and practitioners in the field of English. Each session, the forum was attended by an average of 55 participants. The participants came from different regions in Surabaya and surrounding areas in East Java.

In this study, the targeted participants were determined purposively based on some qualifications implemented to sort the teachers in order to gain specified information for this study; only participants with active status as teachers affiliated to education institution with at least 1 year of teaching experience and those who have attended at least two sessions would be involved. From the mechanism, the research subjects involved in this study were 58 teachers (out of 112 teachers registered during the four sessions in 2019). Based on this rationality, the subjects could be intensively involved in conducting this research both through survey and intensive discussion.

\section{Procedures}

The ELT Best Practices academic forum of which the targeted participants were involved were conducted on February, April, September and November 2019. The data were collected through a mixed-method mechanism, which was preceded by a survey involving the participants of the forum after each session. In addition, the data collection strategy was carried out through interviews by researchers and participants chosen randomly of the targeted participants. This survey was conducted in an effort to collect the perception of English teachers of the English teaching they have done as well as their expectation upon the current trend in the teaching of English.

The survey results were then continued with focus-group discussions involving targeted English teachers to confirm the findings and reflection on the actions that needed. This session was intended to invite teachers to reflect what they have done in their teaching practices, their motivation on joining academic forum and how they perceived this forum in relation with their professional development. In addition, the reflection was also intended to measure to what extent the participants follow the current trend of the teaching of English which are considered would bring benefits to their teaching practices.

A total of 58 teachers as the core data used in this study, from a total of 112 teachers who participated in the ELT Best Practices academic forum throughout 2019. These teachers filled out a survey that included some information, including:

1. Motivation to follow academic forums

2. Understanding of teachers related to the issues / trends that are most warm in teaching English

3. How the activities of the ELT Best Practices academic forum can help teachers improve professionalism

4. How to self-critical reflection in increasing professionalism 
Sueb, Pusparini, R., Trisusana, A., Kurniasih, E., Chakim, N.

5. Some other information included in the survey was teaching experience which is considered important in conducting data analysis.

\section{Data Analysis}

The data obtained from the survey filled out by the participants after each session were analyzed quantitatively in order to find the pattern of the information on the specified focus above. In addition, data through interview were analyzed through thematically to confirm the data from the survey. Data reduction was needed to specify the reflective study of the teachers. In addition, several information related to their background was also utilized as the bases for the analysis.

\section{RESULTS AND DISCUSSION}

\section{Reflection on Teacher's Motivation}

This section discussed the reflection of the teachers particularly in relation with their main motivations participating the academic forum. The rationale of knowing the motivation is to measure their starting point of to what extent the teachers strive to upgrade their competency and professionalism. Another rationale of knowing their motivation is how the academic forum is to help the teachers to upgrade their competency.

The following are the main 3 preferable motivations as conveyed by the teachers participating in the ELT Best Practices academic forum.

TABLE 1 Reflection on English Teacher's Motivation on Joining Academic Forum

\begin{tabular}{lll}
\hline $\begin{array}{l}\text { Most preferable } \\
\text { motivation } \\
\text { Improving teaching technique 40\% }\end{array}$ & $\begin{array}{l}\text { Percenta } \\
\text { ge }\end{array}$ & $\begin{array}{l}\text { Some Inquiries } \\
\text { I can adapt the tips and tricks that I got } \\
\text { from ELT Best Practices in my daily } \\
\text { teaching process }\end{array}$ \\
$\begin{array}{l}\text { Improving English } \\
\text { proficiency }\end{array}$ & $30 \%$ & $\begin{array}{l}\text { Honestly, I wanna join this program } \\
\text { skill which I feel it is starting decreased } \\
\text { since I've been being an English teacher for } \\
\text { elementary and junior high school. } \\
\text { Thbe forum] makes me thirsty of newest } \\
\text { and updated teaching knowledge so that I } \\
\text { can improve my teaching. }\end{array}$ \\
Upgrading knowledge of the $15 \%$ &
\end{tabular}

Source: Data processed 2019

According to the data, the main motivations of most the teachers in participating in the academic forum can be mapped in terms of improving professionalism, believing that by attending academic forums such as ELT Best Practices, workshops, and seminar may help them improve their teaching techniques (40\%). Around one-third of the participants (30\%) believe that the academic forum helps them improve language skills, and the other 15\% participants perceive their participation may enrich their knowledge about the teaching of English (more theoretical or conceptual instead of practical knowledge). The other motivations, which are not dominant, are also considered by the participants namely building network and administrative stuffs.

The three main motivations above represent the three main components in professional development among teachers, namely the understanding of theories or concepts, understanding teaching practices or the implementation of theories or concepts, and the ability to communicate which relies on language skills. Teacher participants consider that the teacher forum is an ideal space for them to learn, both theoretical and practical aspects compared to their work places. Despite the fact that the teacher forum is an immersed session where people have the same intention under the same context, not everything related to teaching practices can be accommodated in one academic 


\section{A reflective study on Indonesian English teacher's expectation from teacher forum for professional development}

forum. Therefore, more than one type of process is needed to improve the teaching profession, such as peer-sharing (peer-coaching) and mentoring.

These two aspects of peer-sharing and mentoring are accommodated by the ELT Best Practice which provides a space for teachers and practitioners to share their teaching experiences- the best way of their teaching (known as "best practice"), which is the best way that is felt to have been successful and is expected to be applied in other context. Most of the materials are action research and contextual assessment. This opportunity allows teacher presenters to theorize their successful teaching practices based on Kumaravadivelu's macro-strategic framework drawn from "theoretical, empirical, and experiential knowledge" (Kumaravadivelu, 2006: 185). These frameworks provide principles to the teacher presenters so that they may reflect and have justification upon their teaching practices; this is in line with the post-method paradigm which is crucial for the teacher's competency as they are able to construct their own theories in their teaching practice and could empower the teachers which are underestimated in the implementation of current existing methods (Can, 2009).

What the participants could learn from the teacher presenters during the peer-sharing (peer-sharing is considered as a more appropriate terms instead of peer-coaching which indicates hierarchic status among the teachers) is the concept of theorizing their teaching practices by reflecting the best practices from the teacher presenters, who are coming from unique and different context and may provide alternative approaches in the classroom. From this session, it is expected there will be an exchange of insight from the teacher presenters and participants for better competency after joining the session. Despite the fact that the emphasis of the best practices has been usually conveyed by presenters who are experienced in teaching, however, there are also presenters who have teaching experience under 10 years (if it cannot be considered as novice teachers) who could still share their best practices, namely when the teaching context is very casuistic, such as how to teach English in remote areas where there is no electricity or internet access at all.

In addition to the peer-sharing (best practice session), in an effort to accommodate the conceptual or theoretical aspects, the ELT Best Practice academic forum is guided by a mentor, namely senior teacher and/or co-lecturer for each session. This mentor plays an important role in conveying the latest trends in the teaching of English particularly in Indonesia; overall, this session is delivered through research-based approach. As was the case with the implementation of the mentoring as part of the professional development during the $3^{\text {rd }}$ edition of ELT Best Practice in 2019, the material presented by the mentor (a lecturer) was a listening trend in the 21st century. Not only theoretical, the lecturer conveyed some of the latest English language teaching policies by conveying rules and regulations that can be taken into consideration in career development for the teachers, namely to map the expertise, construct appropriate approach in their lesson plan, and also reflective study in their classrooms.

Mentoring is also believed to be effective for personal and professional partnership which usually involves a more experienced practitioner or expert supporting other party who is usually new to the job (Butcher, 2010); in this case, the teacher participants are mentored and recharged by senior teachers and/or lecturers upon theoretical and conceptual information. For pre-service teachers, mentoring has been proven effective to help pre-service teacher's reflective skills for their teaching competency (Nguyen, 2017:83-102) and encourage teacher mentees to acquire subject matter teaching skills and develop teachers' self-reflection and problem-solving skills (Delaney, 2012). For in-service teacher mentoring is important to build relationship among teachers and mentors based on mutual trust leading to professional growth (Halai, 2006). Teacher's motivation in upgrading their conceptual knowledge of teaching English might be accommodated by the presence of co-lecturing session by the senior teachers or lecturers in the academic forum.

One unique case in this study is the motivation to improve English language skills. The ELT Best Practice academic forum basically does not directly accommodate improvement in English language skills. However, indirectly, this forum provides an immersion space where communication is carried out in full in English (despite all the attendees are teachers from the surrounding area), so that it becomes a rare opportunity for teachers to practice English skills. One teacher even said: 


\section{$[\cdots]$}

This workshop (teacher forum) was the only opportunity for me to communicate in full English. In my daily life, I communicate in English with gado-gado (mixed English-Indonesia), because I only teach in junior high and private classes, where students still have low language skills. (MA)

Thus, what makes the main key of teachers in developing the profession is their motivation and goals following the academic forum. Not only workshops, professional development can also be done by attending seminars, gathering discussions, scientific discussions, book review, even internships, of which the skills and competencies above are accommodated well during the session.

\section{Teachers' Reflection on Preferred Topics in the Teaching of English}

In addition to motivation, teachers' basic understanding of the latest issues in teaching English is an important indicator in determining whether someone is considered ready and has clear goals in participating in professional development activities. In the survey, some teachers' understanding and needs in developing professionalism are presented in the graph below:

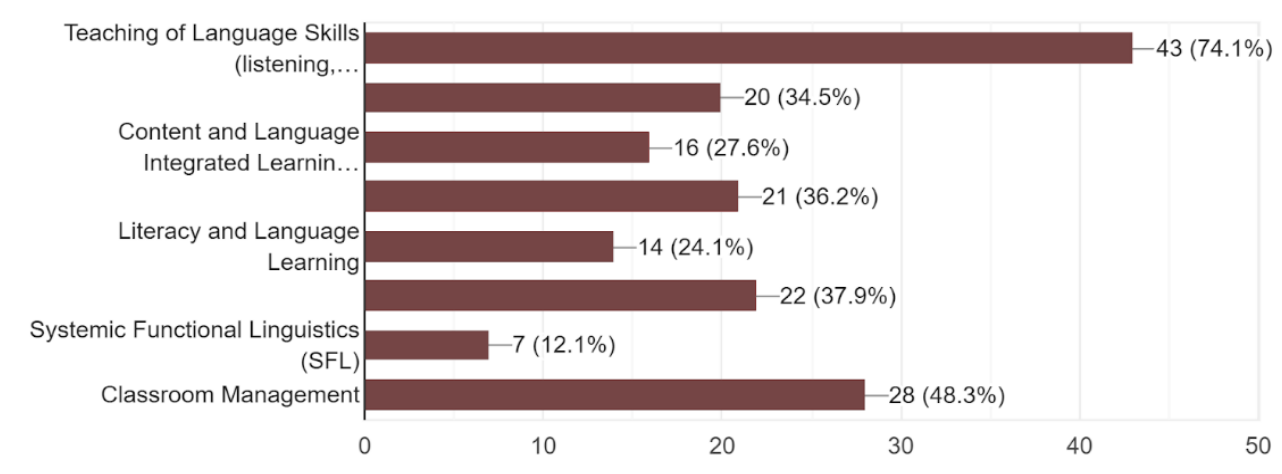

Figure 1 - Preferred Topics for Professional Development

The graph presents common top-5 topic preferences in the teaching of English which become an indicator of how far the teacher participants follows the development of the issue related to the teaching of English as part of their profession. In this case, the teacher has a direction in which to focus the development and what they have to learn. Based on the data, more than $74 \%$ of the teachers believe that the most crucial issue in teaching English is teaching language skills. This is considered reasonable because most respondents are English teachers at secondary school levels (more than 50\% of the participants), where language skills are the main components. In contrast to lecturers in college or students (S1 or graduate), where the focus starts to vary not only about skills, but on aspects of language, literary cases, and content.

The other preferred topics perceived as important for their professional development is classroom management $(48.3 \%)$. As it was asserted by the participants, despite classroom management is considered daily routine scheme that they have to convey, it still becomes crucial issues due to lack of information related to appropriate pedagogical knowledge. Teachers consider classroom management only deals with physical aspects of the classroom with smaller attention to other aspects like student's psychological condition, classroom grouping, task instruction and student's anxiety, and student's engagement; teachers are reluctant to implement and explore the classroom potentials and end up avoiding pedagogical creative initiations in order to create more conducive environment in the language classroom (Lie, 2007; Zulfikar, 2009). It is believed that teachers expect further elaboration on the nature of language classroom management. 


\section{A reflective study on Indonesian English teacher's expectation from teacher forum for professional development}
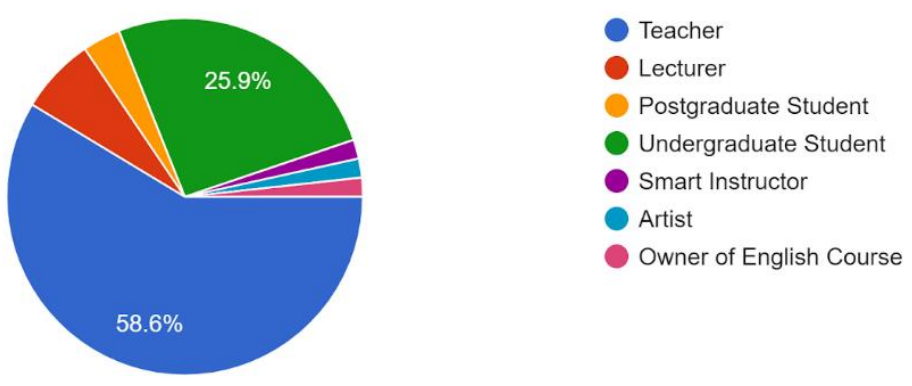

Figure 2 - Profession of the Participants

On the other hand, the least preferred topics by the participants are systemic functional linguistics (SFL) and literacy language learning which are assumed to have small contributions to their classroom. This conception might be because teacher's deficient understanding how to link between the theories to practices in their classroom. For example, the application of SFL in the teaching of English Grammar, in which grammar is taught as a (rhetorical) choice instead of as a strict body of rules, is believed to help students understand the meaning (McCabe, Gledhill, \& Liu, 2015). It means that teachers need to be introduced upon the importance of SFL to their teaching practices in their classroom, especially when dealing with texts and grammar.

Regarding possible missed link between theories and practices among the teacher participants, teachers were encouraged to reflect what they have done for their teaching practices. Based on focusgroup discussion with some teachers to confirm the data on preferred topics above, teachers stated some constructive reflection. During self-reflection, honesty in evaluating oneself is one of the keys to its success; thus, the discussion was carried out in personal manner without being fear of being judged as the mutual trust for professional growth. The process did not take place smoothly as some respondents were not willing to express their weaknesses in the practice of teaching English, rather focusing on what they expect. Some respondents who felt that they were at the point of being saturated so that they need a new thing in teaching English. A respondent said about hope and self-evaluation:

"[...] For the last 4 years, I was a little loose in my spirit because I was bored and stagnant. I was only able to make some good students in English, but in general, our students still had low English [...] Short story, I can score a champion, but most of our students are still low in English. Hopefully by attending various seminars I will find a solution to this problem.” (AD)

From this inquiry, it can be concluded two things that teachers experience like boredom and something new to realign their teaching practices. Uncertain anxiety whether their teaching practice has been wrong so that the ability of students is low even though some students succeed in the race. The teacher's awareness of knowing their weak points and finding solutions to rise is a way of critical self-reflection, criticizing teaching practices and finding solutions. For these respondents, the current solution is to attend teacher forum such as ELT Best Practice, with the hope of getting new ideas in teaching English through peer-sharing and mentoring.

\section{CONCLUSION}

Based on the results and discussion of the research, several conclusions were obtained including motivations of teachers in attending academic forums are mainly to improve teaching practice skills, increase knowledge about the latest ideas and concepts in teaching English, and improve abilities speak English because it is felt that an academic forum is an immerse place where participants use English maximally. In order to indicate their baseline for professional growth, teachers' understanding of 
Sueb, Pusparini, R., Trisusana, A., Kurniasih, E., Chakim, N.

current trends of English language teaching is almost emphasized in teaching language skills. This is because the majority of participants are English teachers in middle and high school levels, so the ability to teach English language skills is important. Classroom management is also considered important despite of their reluctance to implement new approach to create more appropriate classroom environment. Several other issues that are more on content arise, which are dominated by participants with teaching backgrounds in tertiary institutions or undergraduate and graduate students. In carrying out critical reflection, teachers begin to dare to evaluate their own teaching practices. This is a good asset to redirect teaching practices.

\section{REFERENCES}

Bruinsma, M. \& Jansen, E. P.W.A. (2010) Is the motivation to become a teacher related to pre-service teachers' intentions to remain in the profession?, European Journal of Teacher Education, 33:2, 185200, DOI: $10.1080 / 02619760903512927$.

Butcher, J. (2010). A Case for Mentor Challenge? The Problem of Learning to Teach Post-16, Mentoring and Tutoring 10(3), DOI: 10.1080/1361126022000037042.

Can, M. (2009). Post-Method Pedagogy: Teacher Growth behind Walls, Conference: The 10th METU ELT Convention, December 2009.

Delaney, Y.A. (2012). Research on Mentoring Language Teachers: Its Role in Language Education, Foreign Language Annals 45(s1), DOI: 10.1111/j.1944-9720.2011.01185.x.

Farrell, T.S.C. (2012). Reflecting on Reflective Practice: (Re)Visiting Dewey and Schön. TESOL Journal, Volume 3, Issue 1, 7-16. https://doi.org/10.1002/tesj.10

Halai, A. (2006). Mentoring in-service teachers: Issues of role diversity, Teaching and Teacher Education 22(6):700-710, DOI: 10.1016/j.tate.2006.03.007.

Kumaravadivelu, B. (2006). Understanding language teaching: From method to postmethod. Mahwah, NJ: Lawrence Erlbaum.

Lie, A. (2007). Education policy and EFL curriculum in Indonesia: between the commitment to competence and the quest for high scores. TEFLIN Journal. Vol. 18(1), 1-4. DOI: http://dx.doi.org/10.15639/teflinjournal.v18i1/1-15

Liu, K. (2015). Critical reflection as a framework for transformative learning in teacher education. Educational Review 67(2), 135-157. https://doi.org/10.1080/00131911.2013.839546

Marwan, A. (2017). ESP Teaching Challenges in an Indonesian Vocational Higher Institution. The English Teacher, Vol. XXXVIII: 1-12.

McCabe, A., Gledhill, C., \& Liu, X. (2015). Systemic Functional Linguistics and English Language Teaching, TESOL International Journal, Volume 10 Issue 1, pp. 1-10.

Mertens, D.M. 2010. Research and Evaluation in Education and Psychology: Integrating Diversity with Quantitative, Qualitative, and Mixed Methods. Los Angeles: SAGE Publications, Inc.

Mulyasa, E. (2007). Standar Kompetensi dan Sertifikasi Guru. Bandung: PT. Remaja Rosdakarya.

Nguyen, H.T.M. (2017). Models of Mentoring in Language Teacher Education. Switzerland: Springer, Cham. https://doi.org/10.1007/978-3-319-44151-1.

Richard, J.C. \& Farrel, T.S.C. (2005). Professional Development for Language Teachers: Strategies for Teacher Learning. Cambridge: Cambridge University Press.

Widodo H.P. (2016) Teaching English for Specific Purposes (ESP): English for Vocational Purposes (EVP). In: Renandya W., Widodo H. (eds) English Language Teaching Today. English Language Education, vol. 5. Springer, Cham.

Widodo, H. P. (2015). Engaging Students in Literature Circles: Vocational English Reading Programs. The Asia-Pacific Education Researcher 25(2), DOI: 10.1007/s40299-015-0269-7

Yost, D. S. (2006). Reflection and self-efficacy: Enhancing the retention of qualified teachers from a teacher education perspective. Teacher Education Quarterly, 33(4), 59-74.

Zulfikar, T. (2009). The making of Indonesian education: an overview on empowering Indonesian teachers. Journal of Indonesian Social Sciences and Humanities. Vol. 2, 13-39. DOI: 10.14203/jissh.v2i0.19. 
A reflective study on Indonesian English teacher's expectation from teacher forum for professional development 